\title{
A Treasure in Earthen Vessels
}

Wyatt Sawyer

Follow this and additional works at: https://scholarworks.harding.edu/wyatt-sawyer-sermons

\section{Recommended Citation}

Sawyer, W. (1977). A Treasure in Earthen Vessels. Retrieved from https://scholarworks.harding.edu/wyattsawyer-sermons/1168

This Sermon is brought to you for free and open access by the Wyatt Sawyer Archive at Scholar Works at Harding. It has been accepted for inclusion in Wyatt Sawyer Sermon Outlines by an authorized administrator of Scholar Works at Harding. For more information, please contact scholarworks@harding.edu.

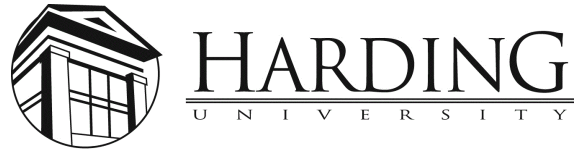




\section{A TREASURE IN EARTHEN VESSELS}

INT: 1*Col. 2:1-3.KJ. A Great, Mysterious

treasure was hidden in God, HS \& Christ.

2. OTHER TRANSLATIONS: This mysterious

treasure is---God's sacred secret. God's

Hidden Truth. God's Secret Plan.

Question: What is that treasure? Go further

3. *II Cor. 4:5-7!! Compare: Rom. 1:16-18. God's power, righteousness, wrath!!!

4. LESSON: How God uses MAN to share His hidden treasure among MEN on earth. Story!

I. HOW A LOST MAN FINDS GOD'S HIDDEN TREASURE.

A. BEGINNING: A sinner, an angel \& a preacher. * Acts 8:26-28.

1. ANGEL went to earthen vessel, not sinner So, NO angel-salvation. Never was!

2. Preacher qualified. * Acts 8:5-13 taught many OTHERS. Note. V. 25, 26.

3. ETHOPIAN EUNUCH: (On 2,000 mi. trip) (F. W. to Bangor, Maine) TO WORSHIP!!!!! a. A Jew or a prosolyte! V. 27. Pentecost b. Bachelor. Alone, but not lonely. V.28 c. Rich-powerful, but not carnal. V.28 d. BUSY, but not secular. When could hau been working on BOOKS, was his SOUL!!

e. LOST, but not in despair. Looking for his Messiah and Savior.

B. CONFRONTATION: Sinner, H. S. \& Preacher. * V. 29-34.

1. H.S. went to earthen vessel, not sinner (No sal. by dir. oper. of H. S.)

V. 30 2. Preacher asked the bold \& brazen questis

(Note: 1978 MT evangelism--bold and brazen questions: "DO YOU KNOW THE ANSWERS?"approach to our neighbors.) It worked then, it will work NOW!! ! !

3. EUNUCH. Reading when could be sleeping or viewing the scenery. Honest!*31-34.

C. THE GREAT MYSTERY IS UNVEILED.

* V. 35. What did he say? WE KNOW!!!

1. * I Cor. 15:1-8. Explains John 3:16. 
D. WHAT LED TO HIS OUTBURST OF REJOICING? $V$. 39c. 1. ONE THING!/ WHAT?/ 3 parts:

a. He UNDERSTOOD the mystery now! V. 35!

b. He BELIEVED God! Word! Treasure!!

c. He OBEYED his Lord.*V. 36-39.

2. Why did he rejoice so??????

5 reasons!

a. Sins forgiven! Relieved. Unburdened.

b. Added to God's Family---the Church.

c. Born again----completely NEW start.

d. Put on Christ!---a new Iifestyle.

e. Comforted in his new HOPE of eternal life in Heaven with God!! J. 14:1-3.

INV. This TREASURE is offered to EACH of you in this aud. today! Can be Bap. upon making the same Good Confession. V. 37.

WE are here to assist you in your obed. BAPTISTRY is filled and ready.

BAPTISMAL CLOTHES are available right now. GOD in Heaven is waiting for your answer. ANGELS around His throne breathlessly wait.

JESUS watches to see what you will do!

WONT YOU COME TO JESUS RIGHT NOW AS WE

SING THIS BEAUTIFUL SONG TO ENCOURAGE YOU??? 